\title{
Removal of Steroid Estrogens in Carbonaceous and Nitrifying Activated Sludge
}

Processes

Ewan J. McAdam ${ }^{\text {a }}$, John P. Bagnall ${ }^{\mathrm{a}}$, Yoong K.K. Koh ${ }^{\mathrm{b}}$, Tze Y. Chiu', Simon Pollard ${ }^{\mathrm{a}}$, Mark D. Scrimshaw ${ }^{\mathrm{d}}$, John N. Lester ${ }^{\mathrm{a}}$ and Elise Cartmell ${ }^{\mathrm{a}}$ *

${ }^{a}$ Centre for Water Science, Cranfield University, Bedfordshire, MK43 0AL, U.K.

${ }^{\mathrm{b}}$ Public Utilities Board, Technology and Water Quality Office, 40 Scotts Road No. 15-01, Environmental Building, 228231, Singapore.

${ }^{c}$ AECOM Design Build, Wentworth Business Park, Tankersley, Barnsley, S75 3DL, U.K.

${ }^{\mathrm{d}}$ Institute for the Environment, Brunel University, Uxbridge, Middlesex, UB8 3PH, U.K.

*Corresponding author: Tel.: +0044 (1234) 758366; Fax.: +0044 (1234) 751671; email:

e.cartmell@cranfield.ac.uk

\section{ABSTRACT}

A carbonaceous (heterotrophic) activated sludge process (ASP), nitrifying ASP and a nitrifying/denitrifying ASP have been studied to examine the role of process type in steroid estrogen removal. Biodegradation efficiencies for total steroid estrogens $\left(\Sigma_{\mathrm{EST}}\right)$ of 80 and $91 \%$ were recorded for the nitrifying/denitrifying ASP and nitrifying ASP respectively. Total estrogen biodegradation $\left(\Sigma_{\mathrm{EST}}\right)$ was only $51 \%$ at the carbonaceous ASP, however, the extent of biodegradation in the absence of nitrification clearly indicates the important role of heterotrophs in steroid estrogen removal. The low removal efficiency did not correlate with biomass activity for which the $A S P_{\text {carbonaceous }}$ recorded $80 \mu \mathrm{g} \mathrm{kg}^{-1}$ biomass $\mathrm{d}^{-1}$ compared to 61 and $15 \mu \mathrm{g} \mathrm{kg}^{-1}$ biomass $\mathrm{d}^{-1}$ at the $A S P_{\text {nitrifying }}$ and $A S P_{\text {nitrifying/denitrifying }}$ respectively. This finding was explained by a moderate correlation $\left(r^{2}=0.55\right)$ between total estrogen loading $\left(\Sigma_{\text {EST }} \mathrm{mg} \mathrm{m}^{-3} \mathrm{~d}^{-1}\right)$ and biomass activity ( $\mu \mathrm{g} \Sigma_{\mathrm{EST}}$ degraded $\mathrm{kg}^{-1} \mathrm{~d}^{-1}$ ) and has established the impact of loading on steroid estrogen removal at full scale. At higher solids retention time (SRT), steroid estrogen biodegradation of $>80 \%$ was observed, as has previously been reported. It is postulated that hydraulic retention time (HRT) is as important as SRT as this governs both reaction time and loading. This observation is based on the high specific estrogen activity determined at the $A S P_{\text {carbonaceous }}$ plant, the significance of estrogen loading and the positive linear correlation between SRT and HRT.

Keywords: $\quad$ Estrogen; Carbonaceous; Nitrification; Loading; Activated Sludge 


\section{Introduction}

Natural and synthetic estrogens are endocrine disrupting chemicals (EDC) that can cause adverse effects on the sexual and reproductive systems in wildlife, fish and humans (Purdom et al., 1994; Jobling et al., 1998; Lai et al., 2002a; Lai et al., 2002b; Martin et al., 2005; Martin et al., 2008). In the aquatic environment estrogens may be subject to biotransformation and bioconcentration (Lai et al., 2002b) leading to complex environmental health issues. Estrogens are discharged to sewer from human sources in the conjugated form as sulphates or gluconarides (Koh et al., 2008). Whilst significant reductions in their concentration occur within the sewage treatment works (STWs), secondary biological treatment of wastewater, as presently configured and operated, cannot afford adequate protection of the aquatic environment (Langford and Lester, 2002; Jones et al., 2005; Koh et al., 2008); consequently effluent discharges are major sources of these anthropogenic chemicals to the aquatic environment (Rodgers-Gray et al., 2000; Kirk et al., 2002). Tertiary treatment technologies have been considered as a future solution for steroid estrogen removal, however if possible, modification of the existing STWs to achieve low residual estrogen concentrations is preferable to minimise both investment and environmental cost (Jones et al., 2007) and energy demand.

Previous investigations of full scale biological activated sludge processes (ASP) have reported that effective removal of $>98 \%$ is attainable for natural estrogens, estrone (E1) and 17 $\beta$-estradiol (E2) and $>90 \%$ removal for the synthetic steroid estrogen 17 $\alpha$-ethinylestradiol (EE2) (Anderson et al., 2003). In contrast, low E2 removal of 64 and 19\% was observed in activated sludge processes sited in Germany and Italy respectively (Baronti et al., 2000; Ternes et al., 2004) suggesting that effective estrogen biodegradation is heavily dependent on process or site specific 
parameters. Based on observations at full-scale and laboratory scale, researchers have alluded to the importance of redox conditions (Matsui et al., 2000; Joss et al., 2004), hydraulic retention time (HRT) (Svenson et al., 2003) and solids retention time (SRT) (Johnson and Sumpter, 2001; Clara et al., 2005; Koh et al., 2008) as possible unifying parameters to explain the disparity between reported ASP estrogen removal efficiencies. A recent comparative study of two full-scale ASPs operated at nearidentical SRT (Koh et al., 2009) reported similar estrogen removal of $>90 \%$, however, differing specific biomass activities ( $\mu$ g estrogen degraded per kg biomass per day, where $\Sigma_{E S T}$ is the sum of dissolved and adsorbed components of five studied compounds) of 84 and $39 \mu \mathrm{g} \Sigma \mathrm{EST} \mathrm{kg}^{-1}$ biomass $\mathrm{d}^{-1}$ for the nitrification/denitrification and nitrification/denitrification/phosphorus removal ASP respectively led the authors to conclude that enhancement of estrogen biodegradation could be facilitated by the appropriate microbial population. Particular emphasis has been given to the role of nitrification on the biodegradation of the more recalcitrant EE2; the hypothetical advantage of nitrification has been cited as the augmented cometabolic oxidation observed with other organic compounds in the presence of the ammonium monooxgenase (AMO) enzyme (Vader et al., 2000). Similarly, the potential for estrogen oxidation by K-strategists, a group of micro-organisms capable of competing at low resource levels and characterised by low growth rates (Graham and Curtis, 2003), has been mooted as both of these postulated biodegradation routes also align with the observation that estrogenic degradation is apparently improved at full scale with extended SRT (Clara et al., 2005) which promotes appropriate conditions for complete nitrification to proceed and maximises bacterial diversity. However, the AMO hypothesis for estrogen removal has been recently examined in a study by Gaulke et al. (2008), in which they demonstrate that high degradation rates observed 
by previous investigators under laboratory conditions may result from elevated nitrite concentrations leading to abiotic nitration of EE2. Consequently, the authors latterly hypothesise that at full scale plants, when in the presence of low nitrite concentrations, heterotrophs may be principally responsible for the reduction of EE2 rather than autotrophic micro-organisms, or indeed, abiotic nitration.

This study examines three ASP configurations for carbonaceous, carbonaceous/nitrification or carbonaceous/nitrification/denitrification treatment to examine the impact of process complexity on steroid estrogen removal under typical environmental conditions. Estrogen biodegradation was assessed using E1, E2 and EE2 as these have been cited as the principal contributors to endocrine disrupting activity in STW effluents (Anderson et al., 2003; Gaulke et al., 2008). For completeness, Estriol (E3) and the sulphate conjugate of estrone (E1-3s) were also determined; E1-3s is the only conjugate that has been determined in UK sewage treatment works due to its persistence and its potential for subsequent degradation in the environment (Gomes et al., 2005; Gomes et al., 2009). Specifically this study examines the importance of heterotrophs, process type and total steroid estrogen loading on steroid estrogen biodegradation at conventional STWs.

\section{Materials and methods}

\subsection{Sewage Treatment Works}

Two full-scale STWs (a carbonaceous ASP and a nitrifying/denitrifying ASP) and a medium-scale pilot (nitrifying ASP) sited in the UK were used for this investigation. The nitrifying ASP $\left(A S P_{\text {nit. }}\right)$ was sampled in winter 2007 ; both the nitrifying/denitrifying $\operatorname{ASP}\left(A S P_{\text {nit./denit. }}\right)$ and the carbonaceous $\operatorname{ASP}\left(A S P_{\text {carb. }}\right)$ were sampled in Spring 2008. The representative pilot $A S P_{n i t .}$ was operated on real settled 
sewage at a full scale STW. The $A S P_{\text {nit./denit. }}$ was an Orbal process similar to an oxidation ditch in design and was thus subject to extended HRT (17 to 26 h). Full process configuration and general treatment parameters are detailed in Fig. 1. Five day sampling campaigns were undertaken at each site. For each day, a sampling interval of $6 \mathrm{~h}$ was undertaken to account for residence time and flow variation which resulted in 4 samples taken per day or a total sample number for each site of, $n=16$. Data herein is expressed either as the mean of the total site specific data set $(n=16)$, or where plotted, is expressed as daily averages $(n=4$, Fig. 2$)$. Grab samples were taken to minimise degradation with time. At each sampling interval, wastewater flow data were collected to permit the computation of flow weighted means. Settled sewage, final effluent and returned activated sludge (RAS) samples were collected at each interval in glass borosilicate jars with Teflon lined caps and extracted onto solid phase extraction (SPE) cartridges within 15 min. of collection (Koh et al., 2009).

\subsection{Analytical procedures}

Both dissolved and adsorbed phases were quantified for all steroid estrogen compounds. Prior to quantification, sewage samples were pre-filtered through GF/C filters (VWR, Lutterworth, UK) and subjected to SPE using tC18 cartridges (Waters, Elstree, UK). Analytes were subsequently solvent eluted $(10 \mathrm{~mL}$ methanol $(\mathrm{MeOH}) / 10 \mathrm{~mL}$ dichloromethane (DCM)), evaporated to dryness and reconstituted to $0.2 \mathrm{~mL}$ volume with $\mathrm{DCM} / \mathrm{MeOH}(90: 10 \mathrm{v} / \mathrm{v})$. The sample was injected onto a $5 \mu \mathrm{m}$, $300 \mathrm{~mm}$ x $7.5 \mathrm{~mm}$ gel permeation size exclusion column (GPC) (Polymer lab., Church Stretton, UK) under isocratic conditions (DCM/MeOH, 90:10 v/v) and the fraction corresponding to between 5.5 and $11.5 \mathrm{~min}$. collected. This fraction was dried, reconstituted with hexane and loaded onto a $\mathrm{NH}_{2} \mathrm{SPE}$ cartridge. Non-polar 

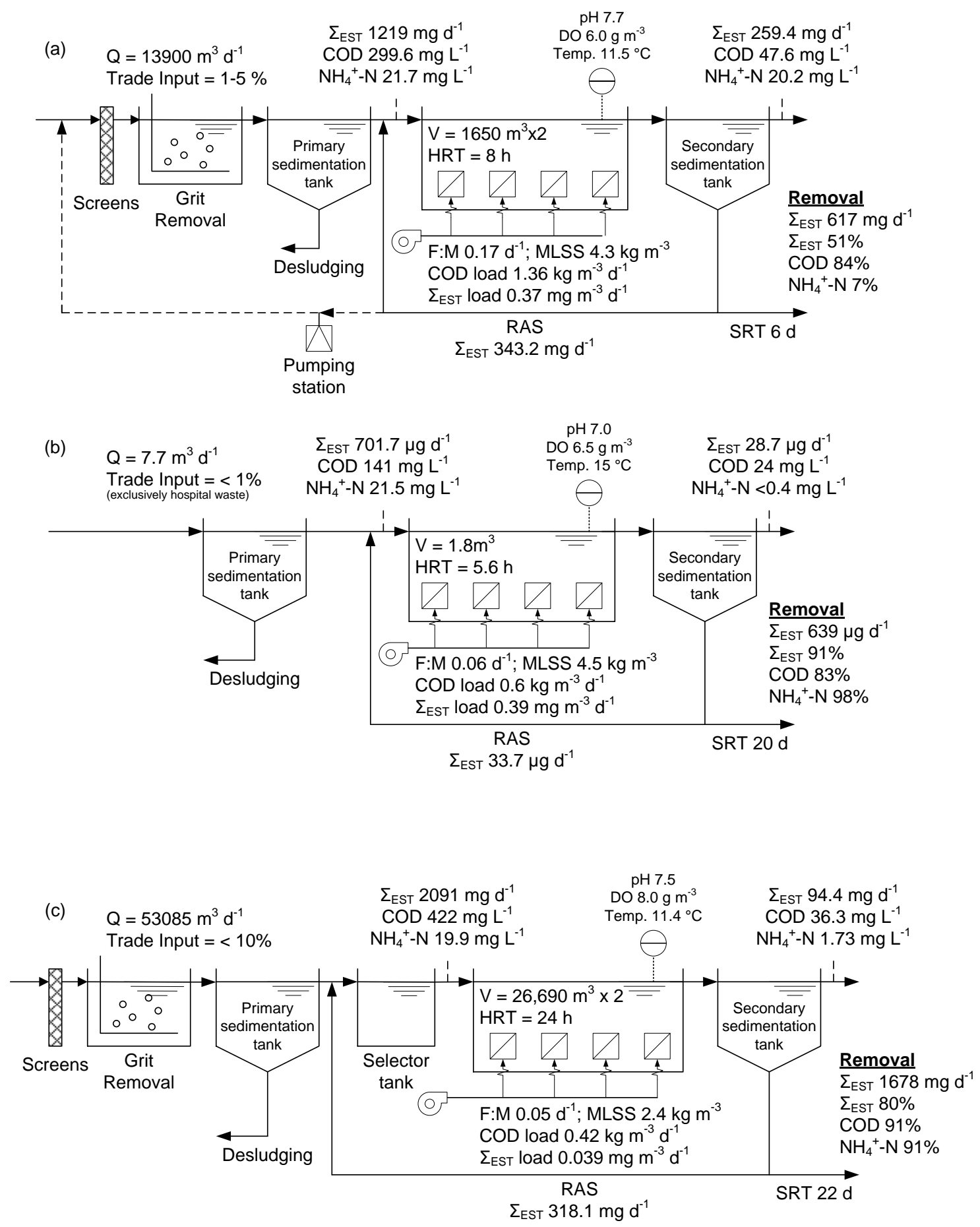

Figure 1. Process flow diagrams inclusive of flow weighted mass balance data. (a) Carbonaceous activated sludge plant $\left(A S P_{c a r b}\right)$. (b) Nitrifying activated sludge plant $\left(A S P_{\text {nit. }}\right)$. (c) Nitrifying/ denitrifying activated sludge plant $\left(A S P_{\text {nit./denit. }}\right)$. Biodegradation was calculated from [settled sewage - (RAS+ final effluent)] 
steroids were initially eluted and then the more polar compounds eluted in a second fraction using $3 \% \mathrm{NH}_{4} \mathrm{OH}$ in methanol. The solid phase retained on the filter papers was freeze-dried and extracted using $10 \mathrm{~mL}$ ethyl acetate whilst being mechanically agitated. The supernatant was evaporated to $0.2 \mathrm{~mL}$ volume and reconstituted to $2 \mathrm{~mL}$ with hexane. Cleanup was initially undertaken using $500 \mathrm{mg} / 3 \mathrm{~mL}$ silica SPE cartridges (preconditioned with $6 \mathrm{~mL}$ hexane) which was then eluted with ethyl acetate $(3 \mathrm{~mL})$ followed by methanol $(2 \mathrm{~mL})$. Eluted samples were subject to evaporation and subsequently re-constituted in $2 \mathrm{~mL}$ of $\mathrm{DCM} / \mathrm{MeOH}$ (90:10) followed by secondary GPC clean-up as described above. Further method detail is available in Gomes et al. (2003) and Koh et al. (2007).

All estrogen standards (> 98\% chemical purity) were purchased from Sigma Aldrich (Poole, Dorset, UK). Deuterated $\left(d_{3 / 4 / 5}\right)$ labelled internal standards of estrone$2,4,16,16-d_{4}\left(\mathrm{E} 1-d_{4}\right), 17 \beta-$ estradiol-2,4,16,16,17- $d_{5}\left(\mathrm{E} 2-d_{5}\right)$, estriol-2,4,17- $d_{3}\left(\mathrm{E} 3-d_{3}\right)$, $17 \alpha$-ethynylestradiol-2,4,16,16- $d_{4}\left(\mathrm{EE} 2-d_{4}\right)$ and sodium estrone-2,4,16,16- $d_{4}$ sulfate (E1-3s- $\left.d_{4}\right)$ were obtained from $\mathrm{C} / \mathrm{D} / \mathrm{N}$ Isotopes (QMX Laboratories, Thaxted, UK) with $>98 \%$ chemical purity. Individual stock solutions were prepared in acetonitrile.

Quantification was by LC/ESI(-)/MS/MS consisting of an HPLC (Waters Alliance HPLC system 2695) coupled to a Waters Quattro Premier XE mass spectrometer with a Z-Spray ESI source (Micromass, Altrincham, UK). The steroids were separated on a Gemini C18 column ( $3 \mu \mathrm{m}$ particle size, $100 \mathrm{~mm} \times 2 \mathrm{~mm}$ i.d., Phenomenex, Macclesfield, UK). The mass spectrometer conditions for detection were as follows: capillary voltage, $3.20 \mathrm{kV}$; multiplier voltage, $650 \mathrm{~V}$; desolvation gas flow, $1000 \mathrm{~L} \mathrm{~h}^{-1}$; cone at $-55 \mathrm{~V}$; cone gas flow at $49 \mathrm{~L} \mathrm{~h}^{-1}$; desolvation temperature at $350{ }^{\circ} \mathrm{C}$ and source temperature at $120{ }^{\circ} \mathrm{C}$. Using this method, the limit of detection in 
both settled sewage and final effluents for E1 and E1-3s was $0.1 \mathrm{ng} \mathrm{L}^{-1}$ and for E2, E3 and EE2 was $0.2 \mathrm{ng} \mathrm{L}^{-1}$ (Koh et al., 2007).

Mixed liquor suspended solids (MLSS), mixed liquor volatile suspended solids (MLVSS) and biological oxygen demand (BOD) were determined by standard methods (APHA, 1998). Analysis for chemical oxygen demand, ammoniacal nitrogen, nitrate and nitrite was undertaken using proprietary cell test kits (Merck, West Drayton, UK) with subsequent spectrophotometric determination.

\section{Results and discussion}

\subsection{Steroid estrogen concentration and composition in settled sewage}

Steroid estrogens were principally detected in the aqueous phase which is consistent with previous observations (Desbrow et al., 1998; Koh et al., 2009). However, partitioning coefficient values $\left(\log K_{p}\right)$ for EE2 in the settled sewage of 4.3 and 4.0 were determined at the $A S P_{n i t}$ and the $A S P_{\text {nit./denit. }}$ respectively. The high adsorptive potential of this compound can be explained by the relative hydrophobicity of EE2 with reported values comparable to the octanol-water partitioning coefficient of $\log K_{p} 3.9$ to 4.1 (Johnson and Sumpter, 2001). In contrast, the partitioning coefficient was lower for the $A S P_{c a r b}$ at $\log K_{p} 0.5$. The difference in the adsorptive capacity of the mixed liquors is expected to result from site specific variations in the heterogeneous organic composition of the mixed liquor matrix. Total steroid estrogen concentrations in the settled sewage $\left(\Sigma_{E S T}\right)$ were $81 \pm 13,91 \pm 17$ and $70 \pm 19 \mathrm{ng} \mathrm{L}^{-1}$ for the $A S P_{\text {carb. }}, A S P_{\text {nit. }}$ and $A S P_{\text {nit./denit. }}$ respectively. The principal steroid estrogens were E1 and E3, the sum of which constituted $60 \pm 7,90 \pm 3$ and $86 \pm 17 \%$ of the $\Sigma_{E S T}$ at the $A S P_{\text {carb. }}, A S P_{\text {nit. }}$ and $A S P_{\text {nit./denit. }}$ respectively. Estriol was determined at higher concentrations than E1 (1.1 to 1.8 times); as E3 is the biodegradation product of E1, it 
is possible that some biodegradation/biotransformation occurred prior to secondary treatment (Koh et al., 2009). Total $\Sigma_{E S T}$ loading was calculated to ascertain process performance by normalising $\Sigma_{E S T}$ concentration for activated sludge aeration basin volume. Both the $A S P_{\text {carb. }}$ and $A S P_{\text {nit. }}$ were operated under similar $\Sigma_{E S T}$ loadings at 0.37 and $0.39 \mathrm{mg} \mathrm{m}^{-3} \mathrm{~d}^{-1}$ respectively which compares to ASP data from Koh et al. (2009) of 0.21 to $0.41 \mathrm{mg} \mathrm{m}^{-3} \mathrm{~d}^{-1}$. However, a lower $\Sigma_{E S T}$ loading of $0.039 \mathrm{mg} \mathrm{m}^{-3} \mathrm{~d}^{-1}$ was recorded at the $A S P_{\text {nit./denit. }}$ due to the lower influent concentration observed and extended HRT (ca 17 to $24 \mathrm{~h}$ ).

\subsection{Biodegradation of steroid estrogens}

Removal of $\mathrm{E} 1$ and $\mathrm{E} 2$ in the $A S P_{\text {carb. }}$ were $73 \pm 29$ and $56 \pm 17 \%$ respectively which are lower than have been cited previously at nitrifying/denitrifying and nitrifying/denitrifying/phosphorus ASP (Koh et al., 2009). Lower biodegradation of E1 and E2 in the $A S P_{\text {carb. }}$ may also be related to the high mean E2 concentration of $20.3 \mathrm{ng} \mathrm{L}^{-1}$ in the settled sewage compared to mean E2 values of 2.0 and $4.6 \mathrm{ng} \mathrm{L}^{-1}$ for the $A S P_{n i t .}$ and $A S P_{n i t . / d e n i t .}$ respectively. Total estrogen load in the settled sewage and final effluent from the $A S P_{\text {carb. }}$ were $1219 \pm 512$ and $259 \pm 126 \mathrm{mg} \mathrm{d}^{-1}$ respectively. Using a flow weighted mass balance, a mean $\Sigma_{E S T}$ mass of $616 \mathrm{mg} \mathrm{d}^{-1}(n=16)$ was estimated to have been biodegraded, after accounting for the adsorbed/dissolved fraction recycled as RAS (Fig. 1). A similar mass balance has been performed across a conventional ASP (assumed to be limited to carbonaceous removal) using only $\mathrm{E} 1+\mathrm{E} 2$ and reported settled and final $\Sigma_{E 1+E 2}$ fluxes of 497 and $325 \mathrm{mg} \mathrm{d}^{-1}$ respectively (34\% $\Sigma_{E 1+E 2}$ retained through biodegradation and adsorption mechanisms) (Carballa et al., 2004; Carballa et al., 2007). In comparison, $\Sigma_{E 1+E 2}$ fluxes for the $A S P_{c a r b}$. in this study were $634 \pm 345$ and $148 \pm 91 \mathrm{mg} \mathrm{d}^{-1}$ for the settled and final effluent respectively. 
Using a flow weighted mass balance, this accounts for a mean $\Sigma_{E 1+E 2}$ biodegradation of $51 \%$ (Fig. 1) indicating similar removal capacity to Carballa et al. (2004) and Carballa et al. (2007). Mass fluxes for the $A S P_{\text {nit. }}$ and $A S P_{\text {nit./denit. }}$ were $711 \pm 132 \mu \mathrm{g} \mathrm{d}^{-1}$ and $2091 \pm 1028 \mathrm{mg} \mathrm{d}^{-1}$ in the settled sewage and $29 \pm 6 \mu \mathrm{g} \mathrm{d}^{-1}$ and $94 \pm 80 \mathrm{mg} \mathrm{d}^{-1}$ in the final effluent respectively. This finding suggests that $>80 \% \Sigma_{E S T}$ removal can be achieved through adsorption and biodegradation (Fig. 1) and approximates to $\Sigma_{E S T}$ removals of $>90 \%$ observed for ASP comprising nitrification/denitrification and nitrification/denitrification/phosphorus removal (Koh et al., 2009). These data support the hypothesis that steroid estrogen biodegradation is augmented by the nitrification process (Vader et al., 2000) or the conditions which are conducive to nitrification.

\subsection{Evaluating steroid estrogen removal using biomass activity and loading}

Total steroid estrogen loading was subsequently used to assess the impact on steroid estrogen removal. The calculated biomass estrogen removal activities did not compare to the order of steroid estrogen removal efficiency determined. To illustrate, the highest biomass estrogen removal activity of $80 \pm 39 \mu \mathrm{g}$ (estrogen) $\mathrm{kg}^{-1}$ biomass $\mathrm{d}^{-1}$ was observed at the $A S P_{\text {carb. }}$, compared to $61 \pm 13$ and $15 \pm 3 \mu \mathrm{g} \mathrm{kg}^{-1}$ biomass $\mathrm{d}^{-1}$ for the $A S P_{n i t .}$ and $A S P_{\text {nit./denit. }}$ respectively. A moderate positive correlation $\left(r^{2}=0.55\right)$ between average biomass activity and $\Sigma_{E S T}$ loading for data from this study and that of Koh et al. (2009) (Fig. 2) suggests that steroid estrogen biodegradation follows a pseudo-first order reaction (Eq. 1) as proposed for low concentration micropollutants by Ternes et al. (2004):

$$
r_{\text {decompositon }}=k_{\text {decompositon }} \times M L S S \times C_{\text {dissolved }}
$$

Where $r_{\text {decomposition }}$ is the rate of decomposition, $k_{\text {decomposition }}$ is the rate constant and $C_{\text {dissolved }}$ is the dissolved steroid estrogen concentration. This relationship 
demonstrates that through the application of loading, it is possible to observe concentration dependent removal at full-scale which has only previously been reported under controlled bench scale experiments (Vader et al., 2000). The high biomass activity and modest $\Sigma_{\mathrm{EST}}$ removal determined at the $A S P_{\text {carb. }}$. contradicts the current nitrification hypothesis and implies that effective biodegradation may be more dependent upon process conditions (i.e. concentration and flow) than nitrification specifically, however, these conditions may coincidentally favour nutrient removal. For example, total MLSS concentration (i.e. g MLSS $\mathrm{L}^{-1}$ normalised.volume) will also increase pseudo first-order rate kinetics (Eq. 1) as demonstrated by Cao et al. (2008) using increasingly concentrated activated sludge liquors in batch conditions. This is analogous to nutrient based ASP design, in which extensive basin volumes assure much higher total mixed liquor concentrations $\left(A S P_{\text {nit./denit. }} 128100 \mathrm{~kg}, \mathrm{Q} 53380\right.$ $\left.\mathrm{m}^{3} \mathrm{~d}^{-1}\right)$ in comparison to solely carbonaceous ASP $\left(A S P_{\text {carb. }} 14190 \mathrm{~kg}\right.$, Q $15000 \mathrm{~m}^{3} \mathrm{~d}^{-}$ $\left.{ }^{1}\right)$.

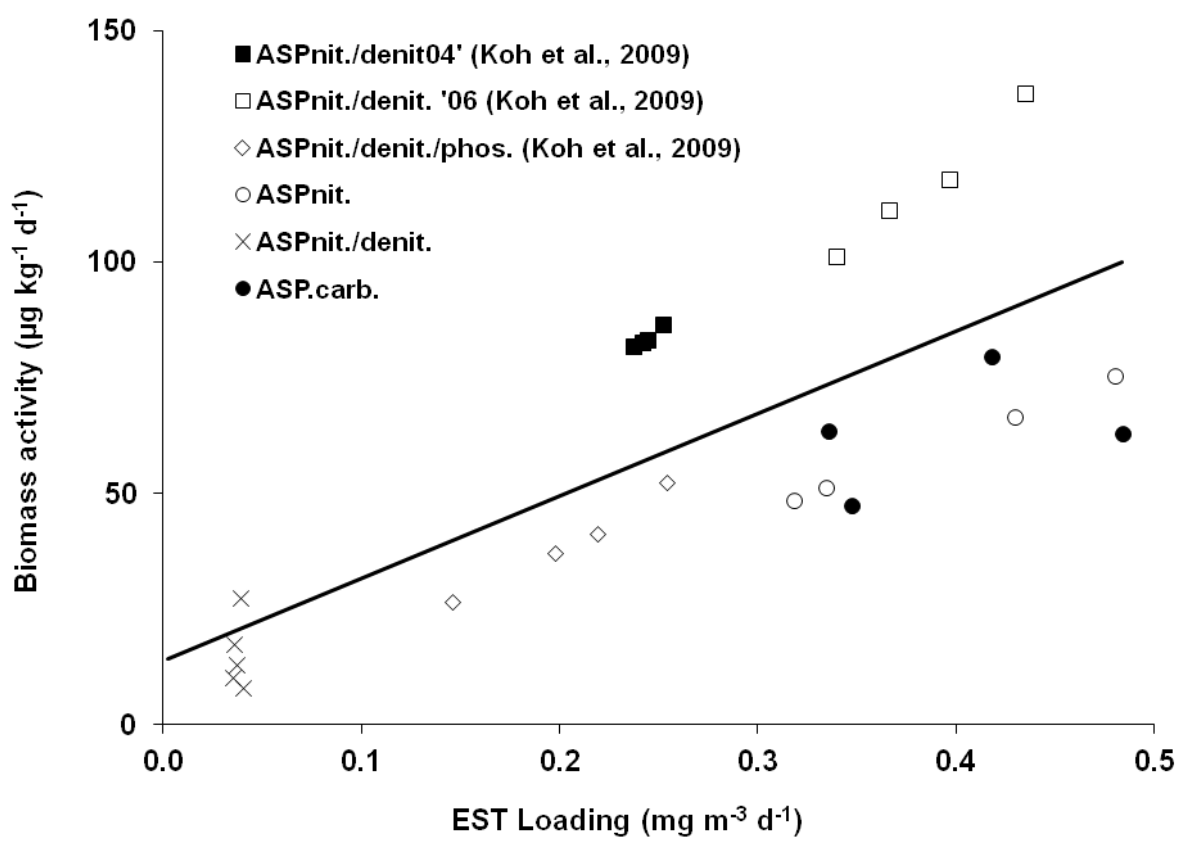

Figure 2. Impact of estrogen loading (total, $\Sigma_{\mathrm{EST}}$ ) on biomass activity (mg $\Sigma_{\mathrm{EST}}$ tonne biomass ${ }^{-1} \mathrm{~d}^{-1}$ ). For each site specific data set, $n=16$; each individual data point represents a single day in the total sampling campaign where $n=4$. 


\subsection{The significance of food to micro-organisms $(F: M)$ ratio}

A food to micro-organisms ratio (F:M) of $0.17 \mathrm{mg}^{\mathrm{BOD}} \mathrm{mg} \mathrm{MLVSS} \mathrm{d}^{-1}$ was observed at the $A S P_{\text {carb. }}$ compared to 0.06 and $0.05 \mathrm{mg}$ BOD mg MLVSS d ${ }^{-1}$ at the $A S P_{n i t .}$ and $A S P_{\text {nit./denit. }}$ respectively. Joss et al. (2004) postulated that low estrogen removal efficiencies determined at higher substrate concentrations (i.e. high F:M) may be due to preferential substrate selection. Although this may be the case, it is interesting to observe a correlation $\left(r^{2}=0.59\right)$ between COD loading and EST loading. Of significance is the concept that high F:M ratios (generally at low SRT) are typically due to the adoption of shorter HRT rather than variations in settled sewage substrate concentration, thus a commensurate increase in $\Sigma_{E S T}$ loading will occur as F:M increases, as observed in this study. Johnson and Sumpter (2001) adapted a pseudo first order E1 rate kinetic from batch studies $\left(k 0.0693 \mathrm{~h}^{-1}\right)$ to explain the relatively low biodegradation of the moderately biodegradable E1 (ca 62\%) implying that HRT was insufficient to achieve the effluent quality of other ASP. Clearly if biodegradation is rate specific, by increasing $\mathrm{F}: \mathrm{M}, \Sigma_{E S T}$ loading is increased and reaction time reduced thus the $A S P_{c a r b}$. is potentially underdesigned for estrogen removal. For example, the low F:M $\left(0.05 \mathrm{~d}^{-1}\right)$ and low $\Sigma_{E S T}$ loading of $0.039 \mathrm{mg} \mathrm{m}^{-3} \mathrm{~d}^{-}$ ${ }^{1}$ at the $A S P_{\text {nit./denit. }}$ was due to the extended HRT (17 to $24 \mathrm{~h}$ ) and aeration tank volume $\left(53380 \mathrm{~m}^{3}\right)$. In comparison, the flow of settled sewage to the $A S P_{\text {carb. }}$ was $33 \%$ of the $A S P_{\text {nit./denit. }}$ using an aeration tank only $6 \%$ of the $A S P_{\text {nit./denit }}$ tank size.

\subsection{The influence of solids retention time on microbiological consortia}

Process mass balances demonstrated that the conditions established by the integration of nitrification and nitrification/denitrification was significant in achieving 
high estrogen biodegradation as only $51 \% \Sigma_{E S T}$ biodegradation was determined at the $A S P_{\text {carb. }}$. Using the validated model of Rittmann et al. (1999) for the estimation of the proportion of ammonia oxidising bacteria (AOB) within the mixed liquor (Eq. 2), ca 5 $\mathrm{mg} \mathrm{L} \mathrm{L}^{-1}$ were present in the $A S P_{\text {carb. }}\left(\left[\mathrm{X}_{\mathrm{a}}\right]_{\mathrm{ao}} / \mathrm{X}_{\mathrm{v}} 0.1 \%\right)$ achieving only $6.9 \%(1.5 \mathrm{mg}$ $\mathrm{NH}_{4}{ }^{+}-\mathrm{N} \mathrm{L}^{-1}$ ) removal and is indicative of an underdeveloped autotrophic community.

$$
\frac{\left(X_{a}\right)_{a o}}{X_{v}}=\frac{\frac{\theta_{x}}{\theta}\left(\frac{Y_{a o}}{1+b_{n i t} \theta_{x}} \Delta T K N\right)}{X_{v}}
$$

In contrast, complete nitrification was observed at the $A S P_{\text {nit. }}$ and $A S P_{\text {nit./denit. }}$ with suggested AOB concentrations of ca $133\left(\left[\mathrm{X}_{\mathrm{a}}\right]_{\mathrm{ao}} / \mathrm{X}_{\mathrm{v}} 3.5 \%\right)$ and ca $41 \mathrm{mg} \mathrm{L}^{-1}\left(\left[\mathrm{X}_{\mathrm{a}}\right]_{\mathrm{ao}} / \mathrm{X}_{\mathrm{v}}\right.$ $2 \%$ ) respectively. Interestingly, the biodegradation of $617 \mathrm{mg} \Sigma_{\mathrm{EST}} \mathrm{d}^{-1}$ at the $A S P_{\text {carb. }}$. confirms that a substantial proportion of estrogens can be biodegraded within a microbial community comprised of a limited autotrophic community and at a short SRT (6 days). This follows recent observations by Gaulke et al. (2008) in which it was postulated that biodegradation maybe predominantly heterotrophic following laboratory based evaluation of abiotic EE2 transformation.

Biodegradation data from this study and from Koh et al. (2009) were used to assess the significance of SRT (Fig. 3). The resultant relationship suggests biodegradation of greater than $70 \%$ can be achieved upon increasing SRT to values greater than $10 \mathrm{~d}$ and to more than $80 \%$ once SRT is increased over $20 \mathrm{~d}$. A similar trend was identified by Clara et al. (2005) in which a 'critical' SRT of greater than 10 d was required to achieve increased biodegradation of E1, E2 and E3 $\left(\Sigma_{\mathrm{E} 1+\mathrm{E} 2+\mathrm{E} 3}\right)$; at an SRT of $24 \mathrm{~d}, 98 \% \Sigma_{\mathrm{E} 1+\mathrm{E} 2+\mathrm{E} 3}$ biodegradation was achieved. Longer SRT provides for enrichment of slow growing bacteria thus the establishment of more diverse biocoenosis (Kreuzinger et al., 2004) and may explain the augmented $\Sigma_{\text {EST }}$ biodegradation observed at the $A S P_{\text {nit. }}$ operated with a relatively short HRT of $5.6 \mathrm{~h}$; 
however, more fundamental information connecting transient floc physiology and SRT is also required, for example, to elucidate the impact of increasing hydrophobicity with SRT (Liao et al., 2001). Importantly, at full scale, HRT is intrinsically extended with increasing SRT $\left(r^{2}=0.89\right)$ thus SRT can be indirectly correlated to pseudo first order reaction kinetics in addition to consortia enhancement. The relevance of this relationship is compounded when considering the slower reaction rates of the more recalcitrant estrogens. Using radio labelled ${ }^{14} \mathrm{C}-17 \alpha-$ ethinylestradiol, Layton et al. (2000) established a rate constant of $k=0.012 \mathrm{~h}^{-1},>25$ times below that observed for ${ }^{14} \mathrm{C}-17 \beta$-estradiol, which resulted in incomplete degradation after $24 \mathrm{~h}$. Based on the quantity of $\Sigma_{\mathrm{EST}}$ biodegradation observed at the $A S P_{c a r b}$, further biodegradation may be achieved through extension of the HRT.

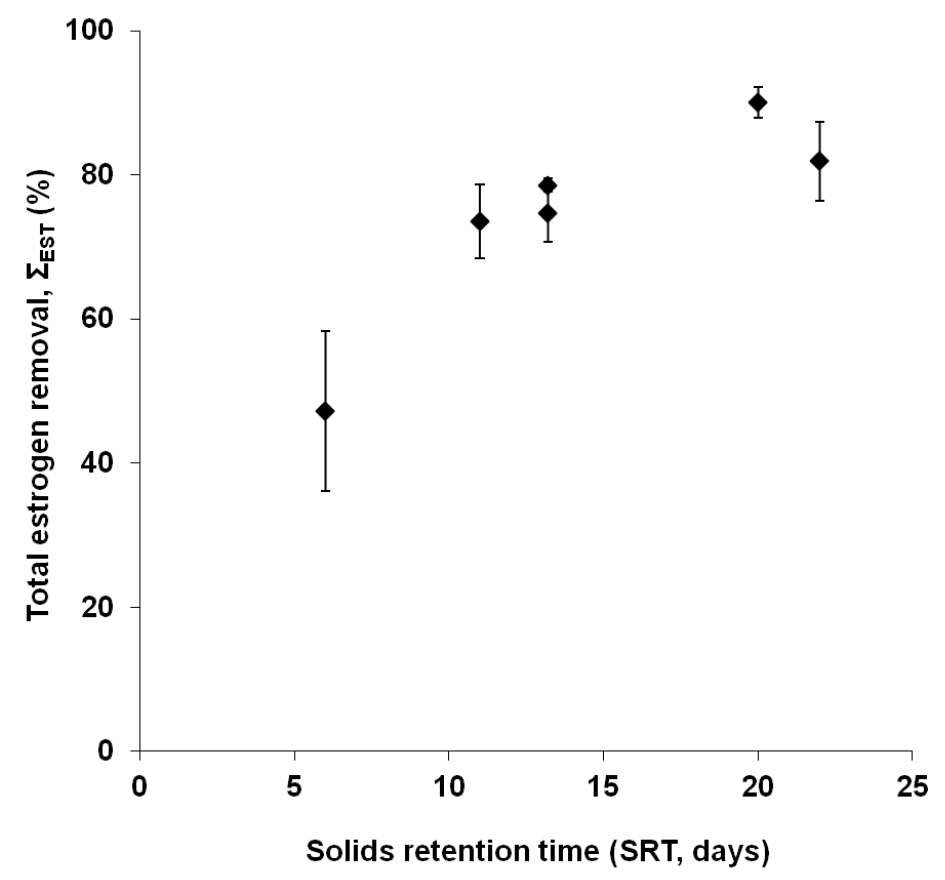

Figure 3. Impact of solids retention time (days) on the biodegradation of steroid estrogens (reported as a total $\left(\Sigma_{E S T}\right), \mathrm{n}=16$ ). Biodegradation was calculated from [settled sewage - (RAS+ final effluent)]. (c) Correlation between HRT and SRT at full-scale works. 
The concentrations of $\mathrm{E} 1$ in the final effluent in this study were $5 \pm 3,1 \pm 0.5$ and $3 \pm 2 \mathrm{ng} \mathrm{L}^{-1}$ for the $A S P_{\text {carb. }}, A S P_{\text {nit. }}$ and $A S P_{\text {nit./denit }}$ respectively (Fig. 4) which is within the range of 3 to $9.3 \mathrm{ng} \mathrm{L}^{-1}$ reported in several European studies (Belfroid et al., 1999; Baronti et al., 2000; Ternes et al., 2004). Predicted no-effect concentrations (PNEC) were applied as a surrogate compliance measure (Environment Agency of England and Wales, 2002). Both the $A S P_{\text {nit. }}$ and $A S P_{\text {nit./denit }}$ (nitrifying plants) met PNEC values for $\mathrm{E} 1$ and $\mathrm{E} 2$ of 3 and $1 \mathrm{ng} \mathrm{L^{-1 }}$ respectively. However, all three sites failed to meet the EE2 PNEC value of $0.1 \mathrm{ng} \mathrm{L}^{-1}$ with effluent values ranging from 0.4 to $1.2 \mathrm{ng} \mathrm{L}^{-1}$ for all three ASP. The extent of non-conformity was compounded when evaluating effluent quality normalised on the basis of toxic equivalents (EEQ, Eq.3).

$\frac{17 \alpha-\text { ethinylest radiol }}{P N E C=0.1}+\frac{17 \beta-\text { estradiol }}{P N E C=1}+\frac{\text { Estrone }}{P N E C=3}=<1$

EEQ values of $18.6,7.2$ and 5.7 were determined for the $A S P_{c a r b}, A S P_{\text {nit. }}$ and $A S P_{n i t . / d e n i t}$ respectively. In general, effluent quality improved with increasing process complexity which reflects the relative effluent EE2 concentrations and confirms the recalcitrance of this compound (Joss et al., 2004).

\section{Conclusions}

The ASP designed for nitrogen removal can achieve higher total estrogen removal efficiencies than carbonaceous only ASP. However, relatively high concentrations of estrogen were removed in the absence of nitrogen removal implying that effective biodegradation can proceed in heterotrophic dominated microbial consortia. Furthermore, the biomass activity data reported herein, suggests estrogen 
biodegradation is concentration dependent and follows a pseudo-first order relationship. Assuming first-order kinetics, it is postulated that by oversizing the $A S P_{\text {carb. }}$ aeration basin volume to increase total mixed liquor concentrations and by extending the SRT, substantial improvements in heterotrophic steroid estrogen biodegradation could be demonstrated; although this may concomitantly induce fortuitous nitrification.

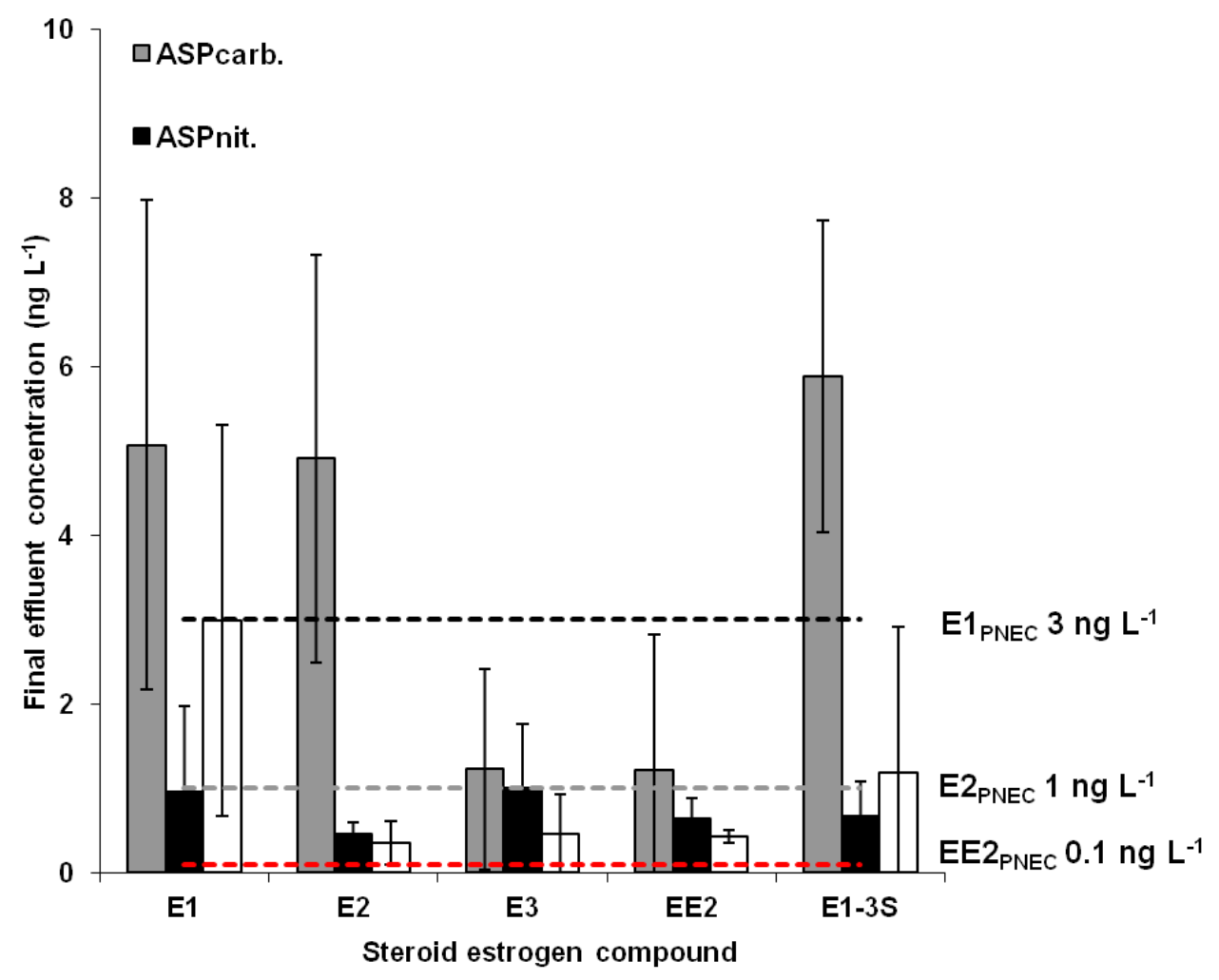

Figure 4. Mean final effluent concentrations $(n=16$, standard deviation plotted as error bars). Individual estrogens: Estrone (E1), 17 $\beta$-estradiol (E2), estriol (E3), 17 $\alpha$ ethinylestradiol (EE2) and the sulphate conjugate of estrone (E1-3s). $\Sigma_{\mathrm{EST}}$, mean sum of steroid estrogens. PNEC indicated proposed no effect concentrations for E1 (3 ng $\left.\mathrm{L}^{-1}\right)$, E2 (1 ng L $\left.{ }^{-1}\right)$ and EE2 $\left(0.1 \mathrm{ng} \mathrm{L}^{-1}\right)$. 


\section{Acknowledgements}

Y.K.K.K. is grateful to the Public Utilities Board of Singapore for the award of a PhD scholarship. We thank the following companies: Anglian Water Ltd., Severn Trent Water Ltd., Thames Water Utilities Ltd., United Utilities Plc. and Yorkshire Water Services Ltd. for providing their support and funding. Finally, Dan McMillan at Waters Ltd. is acknowledged for analytical support.

\section{References}

American Public Health Association (APHA) 1998. Standard Methods for the Examination of Water and Wastewater, 20th edition. American Public Health Association, Washington, DC, USA.

Anderson, H., Siegrist, H., Halling-Sørensen, B., Ternes, T.A., 2003. Fate of estrogens in a municipal sewage treatment plant. Environ. Sci. Technol. 37, 4021-4026.

Baronti, C., Curini, R., D'Ascenzo, G., Di Corcia, A., Gentili, A., Samperi, R., 2000. Monitoring natural and synthetic estrogens at activated sludge sewage treatment plants and in a receiving water. Environ. Sci. Technol. 34, 50595066.

Belfroid, A.C., Van der Horst, A., Vethaak, A.D., Schafer, A.J., Rijs, G.B.J., Wegener, J., Cofino, W.P., 1999. Analysis and occurrence of estrogenic hormones and their glucuronides in surface water and waste water in The Netherlands. Sci. Total Environ. 225, 101-108.

Cao, Q., Yu, Q., Connell, D.W., 2008. Degradation rate constants of steroids in sewage treatment works and receiving water. Environ. Technol. 29, 13211330.

Carballa, M., Omil, F., Lema, J.M., 2007. Calculation methods to perform mass balances of micropollutants in sewage treatment plants. Application to pharmaceutical and personal car products (PPCPs). Environ. Sci. Technol. 41, 884-890. 
Carballa, M., Omil, F., Lema, J.M., Llompart, M., Garcĭa-Jares, C., Rodrĭguez, I., Gŏmez, M., Ternes, T., 2004. Behaviour of pharmaceuticals, cosmetics and hormones in a sewage treatment plant. Water Res. 38, 2918-2926.

Clara, M., Kreuzinger, N., Strenn, B., Gans, O., Kroiss, H., 2005. The solids retention time - a suitable design parameter to evaluate the capacity of wastewater treatment plants to remove micropollutants. Water Res. 39, 97-106.

Desbrow, C., Routledge, E.J., Brighty, G.C., Sumpter, J., Waldock, M., 1998. Identification of Estrogenic Chemicals in STW Effluent. 1. Chemical fractionation and in vitro biological screening. Environ. Sci. Technol. 32, $1549-1558$

Environment Agency of England and Wales, 2002. Proposed Predicted No-effect Concentrations (PNECs) for natural and synthetic steroid estrogens in surface waters, R\&D Technical Report P2-T04/1; Environment Agency: Bristol, UK.

Gaulke, L.S., Strand, S.E., Kalhorn, T.F., Stensel, H.D., 2008. 17 $\alpha$-ethinylestradiol Transformation via abiotic nitration in the presence of ammonia oxidizing bacteria. Environ. Sci. Technol. 42, 7622-7627.

Gomes, R.L., Scrimshaw, M.D., Lester, J.N., 2003. Determination of endocrine disruptors in sewage treatment and receiving waters. Tr. Anal. Chem. 22, 697707.

Gomes, R.L., Scrimshaw, M.D, Lester, J.N., 2005. Simultaneous determination of natural and synthetic steroid estrogens and their conjugates in aqueous matrices by liquid chromatography/mass spectrometry. Int. J. Environ. Anal. Chem. 85, 1-14.

Gomes, R.L., Scrimshaw, M.D., Lester J.N., 2009. Fate of conjugated natural and synthetic steroid estrogens in crude sewage and activated sludge batch studies. Environ. Sci. Technol. 43, 3612-3618.

Graham, D.W., Curtis, T.P., 2003. In: Head, I.M., Singleton, I., Milner, M.G. (Eds.) Ecological theory and bioremediation. Bioremediation - A Critical Review. Horizon Scientific Press, Norwich, UK.

Jobling, S., Nolan, M., Tyler, C.R., Brighty, G., Sumpter, J.P., 1998. Widespread sexual disruption in wild fish. Environ. Sci. Technol. 32, 2498-2506.

Johnson, A.C., Sumpter, J.P., 2001. Removal of endocrine-disrupting chemicals in activated sludge treatment works. Environ. Sci. Technol. 35, 4697-4703. 
Jones, O.A.H., Green, P., Voulvoulis, N., Lester, J.N., 2007. Questioning the excessive use of advanced treatment to remove organic micropollutants from wastewater. Environ. Sci. Technol. 41, 5085-5089.

Jones, O.A.H., Voulvoulis, N., Lester, J.N., 2005. Pharmaceuticals - A threat to drinking water? Trends Biotechnol. 23, 163-167.

Joss, A., Anderson, H., Ternes, T., Richle, P.R., Siegrist, H., 2004. Removal of estrogens in municipal wastewater treatment under aerobic and anaerobic conditions: Consequences for plant optimisation. Environ. Sci. Technol. 38, 3047-3055

Kirk, L.A., Tyler, C.A., Lye, C.M., Sumpter, J.P., 2002. Changes in estrogenic and androgenic acitivities at different stages of treatment in wastewater treatment works. Environ. Toxicol. Chem. 21, 972-979.

Koh, Y. K. K., Chiu, T.Y., Boobis, A., Cartmell, E., Lester, J.N., Scrimshaw, M.D., 2007. Determination of steroid estrogens in wastewater by high performance liquid chromatography - tandem mass spectrometry. J. Chromatogr. A 1173, 81-87.

Koh, Y.K.K., Chiu, T.Y., Boobis, A., Cartmell, E., Scrimshaw, M.D., Lester, J.N., 2008. Treatment and removal strategies of natural estrogens in the wastewater. Environ. Technol. 29, 245-268.

Koh, Y.K.K., Chiu, T.Y., Boobis, A.R., Scrimshaw, M.D., Bagnall, J.P., Soares, A., Pollard, S., Cartmell, E., Lester, J.N., 2009. The influence of operating conditions on the biodegradation of steroid estrogens and nonylphenolic compounds during wastewater treatment processes. Environ. Sci. Technol. 43, 6646-6654.

Kreuzinger, N., Clara, M., Strenn, B., Kroiss, H., 2004. Relevance of the sludge retention time (SRT) as design criteria for wastewater treatment plants for the removal of endocrine disruptors and pharmaceuticals from wastewater. Water Sci. Technol. 50(5), 149-156.

Lai, K.M., Scrimshaw, M.D., Lester, J.N., 2002a. Prediction of the bioaccumulation factors and body burden of natural and synthetic estrogens in aquatic organisms in river systems. Sci. Total Environ. 289, 159-168.

Lai, K.M., Scrimshaw, M.D., Lester, J.N., 2002b. The effects of natural and synthetic steroid estrogens in relation to their environmental occurrence. Crit. Rev. Toxicol., 32, 113-132. 
Langford, K., Lester, J.N., 2002. Chapter 4, Fate and behaviour of endocrine disruptors in wastewater treatment processes. In: Birkett, J.W., Lester, J.N. (Eds.). Endocrine Disruptors in Wastewater and Sludge Treatment Processes. CRC Press, Boca Raton, FL.

Layton, A.C., Gregory, B.W., Seward, J.R., Schultz, T.W., Sayler, G.S., 2000. Mineralization of Steroidal Hormones by Biosolids in Wastewater Treatment Systems in Tennessee U.S.A. Environ. Sci. Technol. 34, 3925-3931.

Liao, B.Q., Allen, D.G., Droppo, I.G., Leppard, G.G., Liss, S.N., 2001. Surface properties of sludge and their role in bioflocculation and settleability. Water Res. 35, 339-350.

Martin, O.V., Scrimshaw, M.D., Lester, J.N., Lai, K.M., 2005. Receiver Operating Characteristics (ROC) analysis for environmental diagnosis. A potential application to endocrine disruptors screening: In Vitro estrogenicity bioassays. Environ. Sci. Technol. 39, 5349-5355.

Martin, O.V., Shialis, T., Lester, J.N., Scrimshaw, M.D., Boobis, A.R., Voulvoulis, N., 2008. Testicular dysgenesis syndrome and the estrogen hypothesis: A quantitative meta-analysis. Environ. Health Persp. 116, 149-157.

Matsui, S., Takigami, H., Matsuda, T., Taniguchi, N., Adachi, J., Kawami, H., Shimizu, Y., 2000. Estrogen and estrogen mimics contamination in water and the role of sewage treatment. Water Sci. Technol. 42(12), 173-179.

Purdom, C.E., Hardiman, P.A., Bye, V.J., Eno, N.C., Tyler, C.R., Sumpter, J.P., 1994. Estrogenic effects of effluent from sewage treatment works. Chem. Ecol. 8, $275-285$.

Rodgers-Gray, T.P., Jobling, S., Morris, S., Kelly, C., Kirby, S., Janbakhsh, A., Harries, J.E., Waldock, M.J., Sumpter, J.P., Tyler, C.R., 2000. Long-term temporal changes in the estrogenic composition of treated sewage effluent and its biological effects on fish. Environ. Sci. Technol. 34, 1521-1528.

Rittmann, B.E., Laspidou, C.S., Flax, J., Stahl, D.A., Urbain, V., Harduin, H., van der Waarde, J.J., Geurkink, B., Henssen, M.J.C., Brouwer, H., Klapwijk, A., Wetterauw, M., 1999. Molecular and modelling analyses of the structure and function of nitrifying activated sludge. Water Sci. Technol. 39, 51-59.

Svenson, A., Allard, A.S., Ek, M., 2003. Removal of estrogenicity in Swedish municipal sewage treatment works. Water Res. 37, 4433-4443. 
Ternes, T.A., Joss, A., Siegrist, H., 2004. Scrutinizing pharmaceutical and personal care products in wastewater treatment. Environ. Sci. Technol. 38, 393A-399A.

Vader, J.S., Van Ginkel, C.G., Sperling, F.M.G.M., De Jong, J., De Boer, W., De Graaf, J.S., Van Der Most, M., Stokman, P.G.W., 2000. Degradation of ethinyl estradiol by nitrifying activated sludge. Chemosphere 41, 1239-1243. 